\title{
Reproduction and beyond, kisspeptin in ruminants
}

\author{
Joseph A. Daniel', Chad D. Foradori ${ }^{2}$, Brian K. Whitlock ${ }^{3}$ and James L. Sartin ${ }^{2 *}$
}

\begin{abstract}
Kisspeptin (Kp) is synthesized in the arcuate nucleus and preoptic area of the hypothalamus and is a regulator of gonadotropin releasing hormone in the hypothalamus. In addition, Kp may regulate additional functions such as increased neuropeptide $Y$ gene expression and reduced proopiomelanocortin (POMC) gene expression in sheep. Other studies have found a role for Kp to release growth hormone $(\mathrm{GH})$, prolactin and luteinizing hormone (LH) from cattle, rat and monkey pituitary cells. Intravenous injection of Kp stimulated release LH, GH, prolactin and follicle stimulating hormone in some experiments in cattle and sheep, but other studies have failed to find an effect of peripheral injection of $\mathrm{Kp}$ on $\mathrm{GH}$ release. Recent studies indicate that $\mathrm{Kp}$ can stimulate $\mathrm{GH}$ release after intracerebroventricular injection in sheep at doses that do not release $\mathrm{GH}$ after intravenous injection. These studies suggest that Kp may have a role in regulation of both reproduction and metabolism in sheep. Since GH plays a role in luteal development, it is tempting to speculate that the ability of $\mathrm{Kp}$ to release $\mathrm{GH}$ and $\mathrm{LH}$ is related to normal control of reproduction.
\end{abstract}

Keywords: Growth hormone, Leptin, Luteinizing, Neuropeptide Y, POMC

\section{Introduction}

Kisspeptin (Kp), also known as metastin, was first discovered and noted for its role in the inhibition of cancer cell metastasis. However, it was discovered to also stimulate gonadotropin releasing hormone $(\mathrm{GnRH})$ release and subsequent secretion of luteinizing hormone. Neuroendocrine control of reproduction in ruminants culminates in the secretion of luteinizing hormone (LH) from the anterior pituitary. There has been much interest in Kp's role in regulation of reproduction in a number of species including ruminants. More recently, $\mathrm{Kp}$ has been implicated in the integration of metabolic control of reproduction. This review will briefly summarize KP action on reproduction in ruminants and focus on recent discoveries of Kp action beyond reproduction control in ruminants.

\section{Review}

Kisspeptin action on luteinizing hormone and gonadotropin Kisspeptin clearly stimulates a release of GnRH and subsequent secretion of LH. Intravenous administration of

\footnotetext{
* Correspondence: sartijl@auburn.edu

Department of Anatomy, Physiology \& Pharmacology, Auburn University, Auburn, AL 36849, USA

Full list of author information is available at the end of the article
}

Kp-10 to ovariectomized (OVX) ewes stimulated increased circulating concentrations of LH and increased GnRH concentrations in the cerebrospinal fluid [1]. Central administration of $\mathrm{Kp}-10$ increased GnRH concentrations in the cerebrospinal fluid and increased LH concentrations in the plasma of sheep [2]. Additionally, $\mathrm{Kp}-10$ increased circulating concentrations of LH in prepubertal male and female Japanese Black calves [3]. Kisspeptin-10 also stimulated increased circulating concentrations of LH in Holstein cows and ovariectomized Jersey cows, and interestingly the sensitivity of LH to exogenous Kp-10 stimulation seems to be enhanced with lactation $[4,5]$. Central administration of the Kp antagonist, peptide 234, to ewes reduced LH pulse amplitude to the point of precluding determination of pulse frequency and reduced mean LH concentrations [6]. Central administration of $\mathrm{p}-271$, another $\mathrm{Kp}$ receptor (Kiss1R) antagonist, also inhibited pulsatile LH concentrations in ovariectomized ewes [7]. Kisspeptin expression is regulated by steroids as the number of $\mathrm{Kp}$ positive cells in the ARC are increased following OVX compared to intact ewes, the opposite being found in the preoptic area (POA) Kp neurons [8]. Furthermore, the number of $\mathrm{Kp}$ positive cells in the arcuate nucleus 
(ARC) is reduced in ovariectomized ewes by treatment with estrogen or progesterone [8]. Additionally, the majority of $\mathrm{Kp}$ positive cells in the ARC also coexpressed the progesterone receptor [8]. Interestingly, single nucleotide polymorphisms in the Kiss1 gene were associated with increased litter size in goats [9].

\section{Kisspeptin and the luteinizing hormone surge}

Kisspeptin appears to have a role in generation of the LH surge to stimulate ovulation. Constant iv infusion of Kp-10 for $8 \mathrm{~h}$ beginning $30 \mathrm{~h}$ after progesterone withdrawal stimulated an earlier LH surge and an earlier increase in circulating concentrations of progesterone than in ewes treated with vehicle [1]. Additionally, IV infusion of $\mathrm{Kp}$-10 also stimulates a surge of LH in anestrous ewes [10]. Blockage of $\mathrm{Kp}$ action with the Kiss1R antagonist, p-271, attenuated an estradiol induced LH surge [8].

The action of Kp on LH in sheep appears to be via an effect on $\mathrm{GnRH}$ release from the hypothalamus and not direct action of $\mathrm{Kp}$ on pituitary gonadotropes. Cultured ovine pituitary cells can respond to $\mathrm{Kp}$ treatment with increased release of $\mathrm{LH}$, but hypothalamo-pituitarydisconnected ewes do not respond to Kp-10 treatment with increased circulating concentrations of LH nor do hypophysial portal concentrations of Kp correspond with LH pulsatility and the LH surge [11]. Furthermore, expression of $\mathrm{Kp}$ (both number of $\mathrm{Kp}$ positive cells and level of expression per cell) was increased in caudal ARC during the late follicular phase of ewes [12]. Smith et al. [13] also observed an increase in the number of Kiss1 mRNA positive cells in the middle and caudal ARC as well as the POA during the late follicular phase. Additionally, the percentage of Kp positive cells expressing Fos was increased by positive estradiol feedback in the middle and caudal ARC [13]. Kisspeptin neurons in the POA showed high levels of Fos activation at the time of the LH surge [14]. The proportion of Kp neurons showing Fos activation was positively correlated with the percentage of GnRH neurons expressing Fos activation [14]. However, very few ARC Kp neurons showed Fos activation around the time of the LH surge [15]. Thus, Kp is clearly involved in generation of the $\mathrm{GnRH}$, and consequentially the LH, surge, although it is not clear if $\mathrm{Kp}$ neurons in the ARC or POA area are more important in generating the $\mathrm{LH}$ surge.

\section{Kisspeptin action in seasonally anestrous animals}

The Kp response to steroid and nonsteroid cues is altered during the nonbreeding season to result in seasonal anestrous in sheep. In ewes, infusion of Kp-10 IV stimulated ovulation during the nonbreeding season [1]. Kisspeptin expression is higher in the breeding season than the nonbreeding season in sheep, and there is an increase in Kp contacts with GnRH neurons during the breeding season [12]. The number of Kp positive cells in the ARC is also higher during the breeding season than the nonbreeding season of ovariectomized ewes [8]. Additionally, the number $\mathrm{Kp}$ positive neurons in the $\mathrm{ARC}$ and the percentage of neurons positive for $\mathrm{Kp}$ in both the ARC and preoptic area increased in OVX, estradiol treated ewes following the transition to short day exposure [16]. The GnRH and LH response to Kp-10 is greater in seasonally anestrous ewes than in luteal ewes during the breeding season [17]. Additionally, expression of the Kp receptor, Kiss1r, mRNA in GnRH neurons is higher during the nonbreeding season than during the breeding season in ewes, and Kiss1r mRNA expression in $\mathrm{GnRH}$ neurons is reduced by Kp-10 treatment of ewes during the non-breeding season but not by steroid treatment of OVX ewes [17]. These results suggest alterations in Kp production or release is involved in the seasonal regulation of reproduction in sheep.

Introduction of a ram to seasonally anestrous ewes isolated from rams for at least one month will induce pulsatile LH secretion and can cause ovulation outside of the breeding season [18]. Kisspeptin has a role in this response. Indeed, De Bond et al. [19] utilized the Kp antagonist ( $\mathrm{p}-271)$ to demonstrate Kp action is necessary for the seasonally anestrous ewes to respond to ram introduction with increased LH. Furthermore, ram introduction also increased the number of Kp positive neurons and Kiss 1 mRNA expression in cells in the rostral ARC [19]. Interestingly, Tac2 mRNA, encoding for neurokinin B, was readily detectable in cells with Kiss 1 mRNA, but was decreased in rostral ARC cells following ram introduction [19].

\section{Kisspeptin action in prepubertal animals}

Puberty in the ruminant is initiated by a decrease in negative feedback inhibition of LH by estradiol. Kisspeptin and neurokinin $\mathrm{B}$, which is co-expressed with $\mathrm{Kp}$ in a number of hypothalamic cells, may play a role in initiation of puberty in ruminants. Injection of senktide, a neurokinin B agonist, in prepubertal ewes was immediately followed by a LH pulse [20]. However, the number of neurokinin B cells in the ARC was not different in prepubertal and post puberty ewes, although there was an increase following ovariectomy [20]. The number of $\mathrm{Kp}$ positive cells in the ARC increased following puberty in intact ewes and was also increased following ovariectomy in prepubertal ewes [20]. Additionally, Redmond et al. [21] observed the number of Kiss 1 positive cells in the POA increased from 25 to 35 weeks of age in ewe lambs, although the number of Kiss 1 positive cells did not appear to be related to increases in LH pulse frequency. However, Redmond et al. [21] did report an increase in Kiss 1 positive cells in the middle ARC that was associated with increased frequency of LH pulses. 
Furthermore, the percentage of GnRH neurons in the POA with Kp positive close contacts was higher in post puberty in ewes and increased following ovariectomy in prepubertal ewes [20]. Hourly intravenous treatment with $\mathrm{Kp}$ is capable of inducing a LH surge followed by elevated concentrations of progesterone, suggesting ovulation, in prepubertal ewe lambs [22]. Thus, Kp has a definite role in initiation of puberty in the sheep, but only in a defined window of receptivity.

\section{Non-Reproductive roles for Kisspeptin Pituitary actions of kisspeptin}

There is circumstantial evidence of possible actions of $\mathrm{Kp}$ at the level of the pituitary in sheep, possibly actions not oriented towards regulation of LH. For example, in sheep the median eminence contains neuron terminals with specific staining for $\mathrm{Kp}$ [23]. Kisspeptin is also released into the portal vein circulation of sheep [11] however the timing of $\mathrm{Kp}$ pulses was concurrent with or follow the LH pulses. This may suggest that $\mathrm{Kp}$ is regulating some pituitary function other than stimulating $\mathrm{LH}$ via GnRH action. Kotani et al. [24] described the presence of Kiss1R in human pituitary followed by studies in sheep which found the presence of Kp receptor mRNA in gonadotropes, lactotropes and somatotropes [8]. The same year, Kadokawa et al. [25] incubated pituitary cells isolated from bovine pituitaries and cultured in the presence of variable doses of Kp-10. The pituitary cells responded to the direct application of $\mathrm{Kp}-10$ in two hours with a dose-dependent increase in secretion of growth hormone $(\mathrm{GH})$ and prolactin. In addition, Gutierez-Pascal et al. [26] found similar results using pituitary cells isolated from rats following treatment with $\mathrm{Kp}-10$ for $30 \mathrm{~min}$ or $4 \mathrm{~h}$. The rat pituitary cells also demonstrated an increase in intracellular $\mathrm{Ca}^{++}$that occurred in $10 \%$ of cultured cells. Moreover, in nonhuman primate pituitary cell culture, Kp-10 stimulated both GH and $\mathrm{LH}$ release through extracellular $\mathrm{Ca}^{++}$entry, phospholipase $\mathrm{C}$, protein kinase $\mathrm{C}$, MAPK, and by additional intracellular $\mathrm{Ca}^{++}$mobilization [27]. These data collectively suggests an intrapituitary signaling system for modification of GH release and perhaps prolactin.

Peripheral administration of Kp-10 to prepubertal heifers increased circulating concentrations of GH [28], suggesting a physiological role to regulate $\mathrm{GH}$ from the pituitary. Moreover, Sébert et al. [10] found that intravenous infusion of $\mathrm{Kp}-10$ to seasonally acyclic ewes produced a surge of LH that was accompanied by a smaller but significant rise in plasma concentrations of both FSH and GH. However, others have reported Kp administration did not alter circulating concentrations of $\mathrm{GH}$ in prepubertal gilts [29], Kp-10 administration did not alter circulating concentrations of $\mathrm{GH}$ in goats [30], lactating dairy cows [5], or prepubertal male or female cattle [3], and $\mathrm{Kp}-10$ administration did not alter plasma $\mathrm{GH}$, prolactin, TSH and cortisol in rhesus monkeys [31]. In OVX cows, intravenous administration of $\mathrm{Kp}-10$ stimulated increased circulating concentrations of $\mathrm{LH}$ regardless of supplemental steroid treatment, but only increased circulating concentrations of $\mathrm{GH}$ in cows treated with pharmacologic doses of estradiol cypionate and/or progesterone [32]. Even in the presence of the steroids, the GH pulse was only $2-3$ fold higher than baseline plasma concentrations with a duration of only $10 \mathrm{~min}$. Thus actions of peripheral $\mathrm{Kp}$ to regulate $\mathrm{GH}$ release are inconsistent and species dependent. In view of the clear actions of $\mathrm{Kp}$ to release $\mathrm{GH}$ in vitro, as well as release $\mathrm{GH}$ after intravenous injection under some conditions, it can be concluded that $\mathrm{Kp}$ has the potential to modify GH through actions at the pituitary, but is probably not a major direct regulator of GH release.

\section{Hypothalamic actions of Kisspeptin}

Infusion of Kp-10 via the lateral ventricle of sheep resulted in an increase in ARC neuropeptide Y (NPY) gene expression and a decrease in proopiomelanocortin gene expression [33]. Since leptin receptors were found in Kp-positive neurons in sheep, this finding suggested a mechanism to coordinate reproduction and metabolic control in sheep. Interestingly, a study in NPY-GFP transgenic mice found that Kiss1r mRNA was produced in NPY neurons [34]. In a hypothalamic cell line, Kim et al. [34] also found that Kp-10 directly regulates NPY neuron synthesis and release, providing more credence to a possible link for $\mathrm{Kp}$ to metabolic control. Since NPY is known to control GH release in ruminants [35], the results of these experiments with NPY suggest that Kp could regulate GH release through the hypothalamus. In an experiment to test this hypothesis, doses of $\mathrm{Kp}-10$ of 100, 200 or 1,000 pmol/kg BW of Kp-10 were administered intravenously to ovariectomized sheep. There was an expected response to increase plasma $\mathrm{LH}$ concentrations, but even at the highest dose of Kp-10, there were no effects on circulating concentrations of GH. Central administration of Kp-10 at 100 or 200 $\mathrm{pmol} / \mathrm{kg} \mathrm{BW}$ increased $\mathrm{GH}$ release as well as the expected release of LH [4]. An example of this effect of Kp to release GH is found in Fig. 1 (unpublished data). Thus $\mathrm{Kp}$, working via hypothalamic mechanisms, provides a strong stimulus to increase GH in addition to its wellknown effects on LH release in sheep.

At present there have been no published findings regarding mechanism or the physiological significance for $\mathrm{Kp}$ in regulating $\mathrm{GH}$. The link between $\mathrm{Kp}$ and NPY [33] and the evidence that NPY releases GH in ruminants [35]), suggests a possible mechanism for $\mathrm{GH}$ regulation by $\mathrm{Kp}$, though to date there have been no direct studies of this proposed pathway. In terms of 


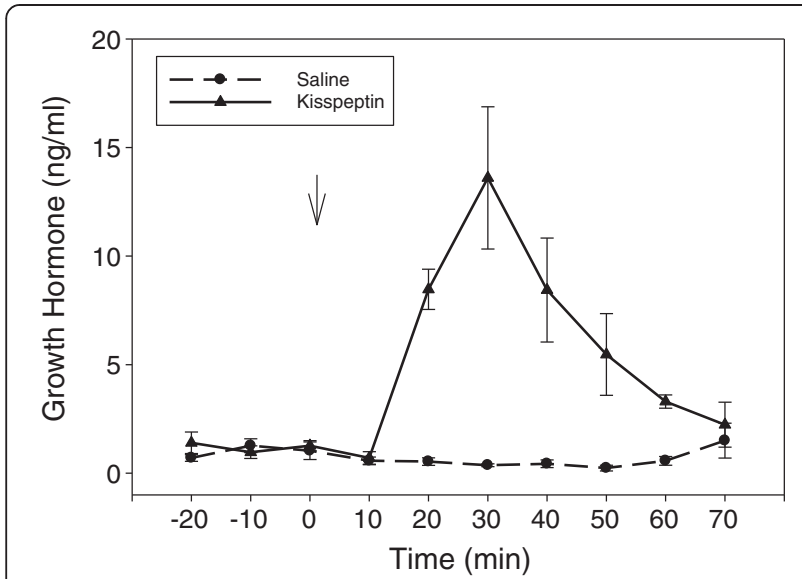

Fig. 1 Effect of intracerebroventricular injection of kisspeptin (200pmol/Kg BW) on circulating concentrations of growth hormone in sheep. (unpublished data)

physiological relevance, the findings that both $\mathrm{LH}$ and $\mathrm{GH}$ are needed for normal luteal growth in sheep suggests that GH release may be linked to reproductive success [36]. Therefore it is tempting to speculate that in addition to direct mechanism regulating $\mathrm{GnRH}$ and hence LH, Kp may also regulate GH through hypothalamic mechanisms and this $\mathrm{GH}$ regulation may be a critical component of normal reproduction in sheep. However, this hypothesis has not yet been directly examined.

\section{Conclusions}

These studies confirm a link between Kp and metabolic regulatory systems. Since adequate nutrition and GH are both needed for reproductive success, the connection of $\mathrm{Kp}$ to metabolic and GH systems may be a critical component of normal reproduction and should be examined in more depth.

\section{Competing interests}

The authors declare that they have no competing interests.

\section{Authors' contributions}

All authors contributed equally to this review. All authors read and approved the final manuscript.

\section{Author details}

'Department of Animal Science, Berry College, Mt. Berry, GA 30149, USA. ${ }^{2}$ Department of Anatomy, Physiology \& Pharmacology, Auburn University, Auburn, AL 36849, USA. ${ }^{3}$ Department of Large Animal Clinical Sciences, University of Tennessee, Knoxville, TN 37996, USA.

Received: 18 November 2014 Accepted: 6 May 2015

Published online: 28 May 2015

\section{References}

1. Caraty A, Smith JT, Lomet D, Ben Said S, Morrissey A, Cognie J, et al. Kisspeptin synchronizes preovulatory surges in cyclical ewes and causes ovulation in seasonally acyclic ewes. Endocrinology. 2007;148:5258-67.

2. Messager S, Chatzidake EE, Ma D, Hendrick AG, Zahn D, Dixon J, et al. Kisspeptin directly stimulates gonadotropin-releasing hormone release via $G$ protein-coupled receptor 54. Proc Natl Acad Sci U S A. 2005;102:1761-6.
3. Ezzat Ahmed A, Saito H, Sawada T, Yaegashi T, Yamashita T, Hirata T, et al. Characteristics of the stimulatory effect of kisspeptin-10 on the secretion of luteinizing hormone, follicle-stimulating hormone and growth hormone in prepubertal male and female cattle. J Reprod Dev. 2009;55:650-4.

4. Whitlock BK, Daniel JA, Wilborn RR, Maxwell HS, Steele BP, Sartin JL. Interaction of kisspeptin and the somatotropic axis. Neuroendocrinology. 2010;92:178-88.

5. Whitlock BK, Daniel JA, Wilborn RR, Maxwell HS, Steele BP, Sartin JL. Effect of kisspeptin on regulation of growth hormone and luteinizing hormone in lactating dairy cows. J Anim Sci Biotech. 2011;2:131-40.

6. Roseweir AK, Kauffman AS, Smith JT, Guerriero KA, Morgan K, PieleckaFortuna J, et al. Discovery of a potent kisspeptin antagonists delineate physiological mechanisms of gonadotropin regulation. J Neurosci. 2009:29:3920-9.

7. Smith JT, Li Q, Yap KS, Shahab M, Roseweir AK, Millar RP, et al. Kisspeptin is essential for the full preovulatory LH surge and stimulates GnRH release from the isolated ovine median eminence. Endocrinology. 2011;152:1001-12.

8. Smith JT, Clay CM, Caraty A, Clarke IJ. KiSS-1 messenger ribonucleic acid expression in the hypothalamus of the ewe is regulated by sex steroids and season. Endocrinology. 2007:148:1150-7.

9. An X, Ma T, Hou J, Fang F, Han P, Yan Y, et al. Association analysis between variants in KISS1 gene and litter size in goats. BMC Genet. 2013;14:63-8.

10. Sébert ME, Lomet D, Saïd SB, Monget P, Briant C, Scaramuzzi RJ, et al. Insights into the mechanism by which kisspeptin stimulates a preovulatory LH surge and ovulation in seasonally acyclic ewes: potential role of estradiol. Domest Anim Endocrinol. 2010;38:289-98.

11. Smith JT, Rao A, Pereira A, Caraty A, Millar RP, Clarke IJ. Kisspeptin is present in ovine hypophysial portal blood but does not increase during the preovulatory luteinizing hormone surge: evidence that gonadotropes are not direct targets of kisspeptin in vivo. Endocrinology. 2008;149:1951-9.

12. Estrada KM, Clay CM, Pompolo S, Smith JT, Clarke IJ. Elevated KiSS-1 expression in the arcuate nucleus prior to the cyclic preovulatory gonadotrophin-releasing hormone/lutenising hormone surge in the ewe suggests a stimulatory role for kisspeptin in oestrogen-positive feedback. J Neuroendocrinol. 2006;18:806-9.

13. Smith JT, Li Q, Pereira A, Clarke IJ. Kisspeptin neurons in the ovine arcuate nucleus and preoptic area are involved in the preovulatory luteinizing hormone surge. Endocrinology. 2009;150:5530-8.

14. Hoffman GE, Le WW, Franceschini I, Caraty A, Advis JP. Expression of Fos and in Vivo median eminence release of LHRH identifies an active role for preoptic area kisspeptin neurons in synchronized surges of $\mathrm{LH}$ and LHRH in the ewe. Endocrinology. 2011;152:214-22.

15. Smith JT, Coolen LM, Kriegsfeld LJ, Sari IP, Jaafarzadehshirazi MG, Maltby M, et al. Variation in kisspeptin and RFamide-related peptide (RFRP) expression and terminal connections to gonadotropin-releasing hormone neurons in the brain: a novel medium for seasonal breeding in sheep. Endocrinology. 2008; 149:5770-82.

16. Chalivvoix S, Bagnolini A, Caraty A, Cognié J, Malpaux B, Dufourny L. Effects of photoperiod on kisspetin neuronal populations of the ewe diencephalon in connection with reproductive function. J Neuroendocrinol. 2010;222:110-8,

17. Li Q, Roa A, Clarke IJ, Smith JT. Seasonal variation in the gonadotropinreleasing hormone response to kisspeptin in sheep: possible kisspeptin regulation of the kisspeptin receptor. Neuroendocrinology. 2012;96:212-21.

18. Keisler DH, Buckrell BC. Breeding Strategies. In: Youngquist RS, editor. Current Therapy in Large Animal Theriogenology. Philadelphia, PA: W. B. Saunders; 1997. p. 603-11.

19. De Bond JP, Li Q, Millar RP, Clarke IJ, Smith JT. Kisspeptin signaling is required for the luteinizing hormone response in anestrous ewes following the introduction of males. PLoS One. 2013;8:1-11.

20. Nestor CC, Briscoe AMS, Davis SM, Valent M, Goodman RL, Hilman SM. Evidence of a role for kisspeptin and Neurokinin B in puberty of female sheep. Endocrinology. 2012;153:2756-65.

21. Redmond JS, Baez-Sandoval GM, Spell KM, Spencer TE, Lents CA, Williams $\mathrm{GL}$, et al. Developmental changes in hypothalamic Kiss 1 expression during activation of the pulsatile release of luteinizing hormone in maturing ewe lambs. J Neuroendocrinol. 2011;23:815-22.

22. Redmond JS, Macedo GG, Velez IC, Caraty A, Williams GL, Amstalden M. Kisspeptin activates the hypothalamic-adenohypophyseal-gonadal axis in prepubertal ewe lambs. Reproduction. 2011;141:541-8. 
23. Pompolo S, Pereira A, Estrada KM, Clarke IJ. Colocalization of kisspeptin and gonadotropin-releasing hormone in the ovine brain. Endocrinology. 2006;147:804-10.

24. Kotani M, Detheux M, Vandenbogaerde A, Communi D, Vanderwinden JM, Le Poul E, et al. The metastasis suppressor gene KiSS-1 encodes kisspeptins, the natural ligands of the orphan G protein-coupled receptor GPR54. J Biol Chem. 2001;276:34631-6.

25. Kadokawa H, Suzuki S, Hashizume T. Kisspeptin-10 stimulates the secretion of growth hormone and prolactin directly from cultured bovine anterior pituitary cells. Anim Reprod Sci. 2008;105:404-8.

26. Gutiérrez-Pascual E, Martínez-Fuentes AJ, Pinilla L, Tena-Sempere M, Malagón MM, Castaño JP. Direct pituitary effects of kisspeptin: activation of gonadotrophs and somatotrophs and stimulation of luteinising hormone and growth hormone secretion. J Neuroendocrinol. 2007;19:521-30.

27. Luque RM, Córdoba-Chacón J, Gahete MD, Navarro VM, Tena-Sempere M, Kineman RD, et al. Kisspeptin regulates gonadotroph and somatotroph function in nonhuman primate pituitary via common and distinct signaling mechanisms. Endocrinology. 2011;152:957-66.

28. Kadokawa H, Matsui M, Hayashi K, Matsunaga N, Kawashima C, Shimizu T, et al. Peripheral administration of kisspeptin-10 increases plasma concentrations of $\mathrm{GH}$ as well as LH in prepubertal Holstein heifers. J Endocrin. 2008;196:331-4.

29. Lents CA, Heidorn NL, Barb CR, Ford JJ. Central and peripheral administration of kisspeptin activates gonadotropin but not somatotropin secretion in prepubertal gilts. Reproduction. 2008;135:879-87.

30. Hashizume T, Saito H, Sawada T, Yaegashi T, Ezzat AA, Sawai K, et al. Characteristics of stimulation of gonadotropin secretion by kisspeptin-10 in female goats. Anim Reprod Sci. 2010;118:37-41.

31. Ramaswamy S, Gibbs RB, Plant TM. Studies of the localisation of kisspeptin within the pituitary of the rhesus monkey (Macaca mulatta) and the effect of kisspeptin on the release of non-gonadotropic pituitary hormones. J Neuroendocrinol. 2009;21:795-804.

32. Whitlock BK, Daniel JA, Wilborn RR, Rodning SP, Maxwell HS, Steele BP, et al. Interaction of estrogen and progesterone on kisspepin-10-stimulated luteinizing hormone and growth hormone in ovariectomized cows. Neuroendocrinology. 2008;88:212-5.

33. Backholer K, Smith JT, Rao A, Pereira A, labal J, Ogawa S, et al. Kisspeptin cells in the ewe brain respond to leptin and communicate with neuropeptide $Y$ and proopiomelanocortin cells. Endocrinology. 2010;151:2233-43.

34. Kim GL, Dhillon SS, Belsham DD. Kisspeptin directly regulates neuropeptide Y synthesis and secretion via the ERK1/2 and p38 mitogen -activated pathways in NPY-secreting hypothalamic neurons. Endocrinology. 2010;151:5038-47.

35. McMahon CD, Elsasser TH, Gunter DR, Sanders LG, Steele BP, Sartin JL. Neuropeptide $Y$ restores appetite and alters concentrations of growth hormone (GH) after central administration to endotoxic sheep. J Endocrinol. 1999;161:333-9.

36. Juengel JL, Nett TM, Tandeski TR, Eckery DC, Sawyer HR, Niswender GD. Effects of luteinizing hormone and growth hormone on luteal development in hypophysectomized ewes. Endocrine. 1995;3:323-6.

\section{Submit your next manuscript to BioMed Central and take full advantage of:}

- Convenient online submission

- Thorough peer review

- No space constraints or color figure charges

- Immediate publication on acceptance

- Inclusion in PubMed, CAS, Scopus and Google Scholar

- Research which is freely available for redistribution 